\title{
PERAN KOMITMEN ORGANISASI SEBAGAI PREDIKTOR ORGANIZATIONAL CITIZENSHIP BEHAVIOR PADA SD SWASTA DI KOTA SERANG
}

\author{
Ika Pratiwi ${ }^{1}$, Uli Wildan Nuryanto ${ }^{2}$, Prof. Muhammad Suparmoko ${ }^{3}$ \\ Program Studi Magister Manajemen Universitas Bina Bangsa \\ ikapratiwix0s@gmail.com
}

\begin{abstract}
ABSTRAK
Tugas dan tanggung jawab seorang guru dalam kondisi pandemi saat ini menjadi semakin berat, bukan hanya menjalankan tugas sehari-hari namun juga dalam mengembangkan kualitasnya untuk menjadi role model dan juga menyiapakan bahan ajar secara digital untuk peserta didiknya. Untuk itu diperlukan sebuah perilaku positif yang mampu meningkatkan kinerja guru dan perilaku tersebut adalah organizational citizenship behaviour (OCB) dimana OCB sendiri dipengaruhi oleh variabel lainnya yaitu komitmen organisasi. Untuk itu penelitian dikembangkan dengan menggunakan pendekatan SEM PLS $2^{\text {nd }}$ order analisis terhadap 248 guru dari 29 Sekolah Dasar Swasta di Kota Serang. Penelitian ini menggunakan. Variabel komitmen organisasi diukur dengan menggunakan 3 dimensi dan 6 indikator sedangkan variabel OCB diukur menggunakan 5 dimensi dan 15 indikator. Hasil analisis terhadap Sembilan hipotesis yang diujikan menunjukan seluruh hipotesis dapat diterima. Dengan besarnya pengaruh variabel komitmen organisasi terhadap OCB sebesar 79,1\% sedangkan sisanya sebesar 20,9\% dipengaruhi variabel lainnya diluar model yang diujikan. Dimensi komitmen afektif menjadi dimensi yang dominan dalam mempengaruhi komitmen organisasi, sedangkan dimensi sportsmanship menjadi dimensi yang paling berpengaruh bagi variabel OCB. Penelitian ini diharapkan mampu menjadi landasan teori bagi pengembangan strategi peningkatan kinerja guru pada Sekolah Swasta di Kota Serang.
\end{abstract}

Kata Kunci: Afektif, Kontinyu, Normatif, Altruism, Conscientiousness, Sportsmanship, Courtesy dan Civic Virtue

\begin{abstract}
The duties and responsibilities of a teacher in the current pandemic condition are increasingly difficult, not only carrying out daily tasks but also in developing their qualities to becomes a role models and also preparing digital teaching materials for their students. For that they needed a positive behaviour that can improve teacher performance and that behaviour is organizational citizenship behaviour (OCB)., where OCB itself influenced by other variables such as organizational commitment. For this reason, the study was developing by using $2^{\text {nd }}$ order approach to analysis 248 sample from 29 private elementary school in Serang city. Organizational commitment measured by using 3 dimension and 6 indicators, while organizational citizenship behaviour measured by using 5 dimension and 15 indicators. This research using 9 hypothesis and from the result shown that all of hypothesis was accepted with the magnitude of the influence of commitment organizational on OCB is $79,1 \%$, while the remaining 20,9\% influenced by others variable outside the model tested. The affective commitment become is the dominant dimension that influencing organizational commitment, while the sportsmanship dimension is the most influential dimension for OCB. This research expected become a theoretical reference as development strategies to improve the teacher performance in the private elementary school at Serang City.
\end{abstract}

Keywords: Affective, Continuous, Normative, Altruism, Conscientiousness, Sportsmanship, Courtesy, Civic Virtue. 


\section{PENDAHULUAN}

Kemajuan era digitalisasi yang begitu cepat dan adanya pandemi covid-19 telah menciptakan sebuah kebiasaan baru yang belum pernah ada sebelumnya di berbagai dimensi kehidupan, salah satunya pada sektor pendidikan. Sistem pembelajaran yang sebelumnya berorientasikan kepada tatap muka mulai digantikan dengan pembelajaran daring, dimana sistem pembelajaran ini menuntut guru untuk dapat meningkatkan kualitasnya. Sehingga dapat memberikan pendidikan yang berkualitas kepada siswanya. Peningkatan kualitas pendidikan menjadi suatu keharusan yang tidak bisa diabaikan, mengingat masa depan suatu bangsa bergantung terhadap keberhasilan bangsa tersebut dalam menciptakan Pendidikan yang berkualitas (Suriana Latif, 2019).

Dalam kondisi normal tanpa adanya pandemi, guru sudah memiliki tugas dan tanggung jawab yang jauh lebih besar, bukan hanya sebatas mendidik, mengajar, membimbing, mengarahkan, melatih, menilai dan mengevaluasi peserta didiknya, namun juga harus bisa menjadi role model (contoh) yang baik dalam menghadapi perubahan zaman menuju revolusi digital terlebih dalam kondisi pandemi saat ini. Untuk dapat menjadi contoh maka guru harus mampu meningkatkan kompetensinya, sehingga diperlukan usaha ekstra, manajemen waktu yang optimal dan perilaku positif dalam meningkatan komptensinya. Untuk dapat menjalankan kesemuanya itu, maka diperlukan suatu modal sumber daya yang berasal dari dalam yaitu organizational citizenship behaviour (OCB).

Organizational citizenship behaviour (OCB) diartikan sebagai suatu perilaku warga organisasi yang dengan sukarela bekerja melebihi standar atau kewajiban yang telah ditentukan oleh organisainya. Artinya, individu memiliki kesadaran untuk bekerja ekstra diluar yang telah dipersyaratkan oleh organisasi dengan penuh kesadaran tanpa adanya paksaan ataupun perintah dari atasan yang pada akhirnya akan mampu berkontribusi positif bagi kemajuan organisasinya. Perilaku inilah yang dibutuhkan pada saat ini untuk menjawab tantangan revolusi digital dan adanya perubahan model pembelajaran pada sekolah dasar. Selain menjalankan kewajibannya sehari-hari dalam mendidik, mengajar, melatih dan membimbing peserta didiknya maka guru harus bekerja ekstra dengan membuat model pembelajaran online yang sebelumnya jarang dilakukan namun saat ini menjadi suatu keharusan. Dimana untuk dapat membuat media pembelajaran online yang menarik, dapat dimengerti, sesuai dengan acuan kurikulum diperlukan pengetahuan dan skill ekstra.

Dengan perilaku OCB yang dimiliki oleh seorang guru, maka sebanyak dan seberat apapun tugas yang menjadi kewajibannya saat ini akan menjadi ringan. Seseorang yang bekerja keras dengan ikhlas dan tulus maka akan menghasilkan kualitas kerja yang optimal, yang pada akhirnya akan meningkatkan kinerja organisasi. OCB juga disebut sebagai perilaku yang bekerja intra-role yaitu 
melakukan tugas dan tanggung jawab seharusnya, namun juga perilaku extra-role yaitu memberikan kinerja maksimal melebihi apa yang diharapkan oleh organisasinya (Organ, 2015).

Perilaku OCB dalam organisasi tidak muncul dengan sendirinya, namun dipengaruhi oleh banyak faktor lainnya, salah satunya adalah komitmen organisasi. Komitmen organisasi adalah kekuatan keseluruhan dari hubungan tunggal dengan penyertaan dalam suatu asosiasi (Steers, 1988). Tanggung jawab otoritatif juga merupakan suatu kondisi di mana seseorang menyukai asosiasi dan membuat upaya yang jujur untuk mengikuti pendaftarannya dalam organisasi sehingga dapat berkontribusi dalam mencapai tujuan organisasinya (Massoudi et al., 2020).

Seseorang yang memiliki tanggung jawab otoritatif akan bekerja dengan komitmen. Seseorang yang sangat berkomitmen secara konsisten percaya bahwa hal utama yang harus dicapai adalah pencapaian tugas dalam asosiasi. Seseorang yang memiliki tanggung jawab otoritatif yang tinggi akan secara konsisten memiliki perspektif yang menggembirakan dan melakukan yang terbaik untuk membantu organisasi (Sungu et al., 2019). Keterikatan antara komitmen organisasi dengan perilaku OCB menjadi sesuati yang menarik untuk dibahas dan digali lebih mendalam. Untuk itulah penelitian ini dilakuan secara komprehensif dan mendalam dengan menggunakan pendekatan yang lebih spesifik bukan hanya mengukur pengaruh antar variabel pada model yang diujikan dengan menggunakan indikator, namun juga secara lebih komprehensif menggali lebih dalam terhadap dimensi apa saja yang lebih dominan berpengaruh terhadap masing-masing variabel, sehingga mampu menjawab fenomena yang ada pada lokus penelitian.

Tanggung jawab hierarkis adalah disposisi yang mencerminkan kesetiaan pekerja pada asosiasi dan interaksi yang konsisten di mana individu yang berwibawa mengekspresikan kecemasan mereka terhadap asosiasi dan pencapaian serta kemajuan yang gigih (Sungu et al., 2019). Tanggung jawab hierarkis adalah suatu kondisi di mana seorang perwakilan menyukai asosiasi tertentu dan tujuannya dan ingin mengikuti pendaftaran dalam asosiasi (Salim \& Noor, 2017). Tanggung jawab hierarkis adalah mentalitas pekerja untuk tetap berada dalam asosiasi dan terlibat dalam upaya untuk mencapai misi, nilai, dan tujuan asosiasi (Putro, 2018).

Tanggung jawab hierarkis adalah disposisi yang mencerminkan kesetiaan pekerja terhadap asosiasi dan interaksi yang konsisten di mana individu yang berwibawa mengekspresikan kecemasan mereka terhadap asosiasi dan kemakmurannya serta kemajuan yang gigih (Risna \& Omar, 2019). Salah satu unsur untuk mewujudkan eksekusi otoritatif yang besar adalah tanggung jawab yang dilakukan oleh semua bagian individu dalam melakukan tugas-tugas hierarkis (Nurwahidah \& Jamil, 2020). Tanggung jawab otoritatif adalah disposisi yang mencerminkan sejauh mana seorang individu mengetahui dan terikat pada pergaulannya (Dahlan, 2020). Tanggung jawab otoritatif adalah suatu 
Prosiding The 1st National Conference on Applied Business, Education, \& Technology (NCABET)"

Unversitas Bina Bangsa 2021

DOI Article : 10.46306/ncabet.v1i1.26

kondisi di mana seorang perwakilan memberkati asosiasi tertentu dan tujuannya dan ingin mengikuti partisipasi dalam asosiasi (Massoud et al., 2020).

Melalui pendekatan filosofi keilmuan, maka secara ontologi penelitian ini dilakukan untuk menjawab tentang apa yang ingin diketahui dari objek yang menjadi pusat penelitian, yaitu menjawab apakah terdapat signifikansi dan seberapa besar pengaruh komitmen organisasi terhadap organizational citizenship behaviour (OCB) dengan menggunakan pendekatan teori resources based view, maka organisasi akan memiliki keunggulan bersaing saat organisasi tersebut memiliki sumber daya yang unggul melebihi yang dimiliki oleh kompetitornya, dan diantara keunggulan itu adalah adalah memiliki perilaku OCB dan juga komitmen organisasi

Ditinjau dari epistimologi, maka penelitian ini menggunakan kajian sumber daya manusia dengan paradigma pemikiran deduktif ke induktif terhadap fenomena melalui kajian literatur dan kajian empiris sampai menjadi sebuah kerangka pemikiran yang terstruktur dan diuji kebenarannya. Sedangkan jika ditinjau dari aspek aksiologi, maka penelitian ini diharapkan mampu berkontrisbusi menjadi acuan teoritis bagi pembaharuan dan pengembangan Sekolah Dasar Swasta di Kota Serang sesuai tuntutan masyarakat, melalui perilaku guru dan komitmen organisasi sebagai unsur terpenting di dalam Lembaga Pendidikan yang mampu menghasilkan peserta didik berkualitas dan sesuai dengan tuntutan perkembangan zaman.

Komitmen organisasi dan OCB merupakan bagian dari keunggulan bersaing yang menjadi modal penting bagi organisasi, mengingat keduanya berasal dari internal organisasi. Memiliki karakteristik yang bernilai (valuable), jarang dimiliki (rare), tidak dapat ditiru (imitability) dan tidak dapat tergantikan (non-substitution). Tidak semua individu memiliki karakteristik dan perilaku tersebut, oleh karenanya OCB dan Komitmen organisasi dapat menjadi pembeda bagi suatu organisasi dibandingkan dengan kompetitornya. Sudarmayasa, (2016) menjelaskan bahwasanya dengan komitmen organisasi yang semakin baik, maka akan meningkatkan extra-role behaviour. Hal ini menggambarkan bahwasanya komitmen afektif, komitmen normative dan komitmen continue akan meningkat sehingga anggota organisasi akan cenderung bekerja melebihi dari apa yang telah dipersyaratkan organisasi.

Komitmen organisasi memiliki pengaruh signifikan terhadap OCB dengan nilai koefisien determinasi yang sangat tinggi, hal ini menunjukan bahwasanya komitmen orgnisasi dapat menjadi prediktor yang dominan terhadap OCB. Dari 627 sampel, didapatkan sebanyak 72 orang atau sebesar $11,48 \%$ memiliki kinerja yang luar biasa, sedangkan sebanyak 108 orang atau sebesar 17,22\% memiliki kinerja diatas ekspektasi yang seharunya, sebanyak 177 orang atau sebesar 28,22 memiliki kinerja sesuai dengan yang diharapkan organisasi sedangkan sisanya sebanyak 270 atau sebesar 43,06\% memiliki kinerja dibawah ekspektasi yang diharapkan organisasi. Salah satu variabel yang 
menjadi pembeda dari pencapaian individu adalah perilaku komitmen organisasi dan OCB (Sitio, 2021).

OCB memiliki dampak positif yang signifikan terhadap kinerja organisasi (Taamneh et al., 2018). Sedangkan Thevanes \& Harikaran (2020) menyimpulkan bahwasanya terdapat hubungan positif dan signifikan antara OCB terhadap kinerja organisasi dan OCB mampu menjadi mediator antara kesimbangan kehidupan kerja terhadap kinerja organisasi. Berdasarkan hasil penelitian terdahulu tersebut, peneliti membuat hipotesis bahwasanya komitmen organisasi berpengaruh signifikan terhadap OCB pada Sekolah Dasar Swasta di Kota Serang dan layak untuk diteliti secara mendalam.

\section{METODE PENELITIAN}

Penelitian ini menggunakan pendekatan kuantitatif dengan paradigma berpikir deduktif menuju induktif dan menggunakan metode survey serta desain deskriptif kausalitas melalui teknik analisis SEM PLS serta alat bantu analisis yang digunakan pada penelitian adalah Smart PLS 3.2.9. Komitmen organisasi diukur dengan menggunakan 3 dimensi dan 6 indikator, sedangkan OCB diukur dengan menggunakan 5 dimensi dan 15 indikator.

Dimensi yang membangun komitmen organisasi adalah komitmen afektif, komitmen kontinyu dan komitmen normatif. Sedangkan dimensi yang menyusun OCB adalah altruism, conscientiousness, sportsmanship, courtesy dan civic virtue. Penelitian dilakukan pada 29 Sekolah Dasar Swasta di Kota Serang, dengan jumlah sampel yang sebanyak 248 guru Sekolah Dasar Swasta di Kota Serang menggunakan purposive sampling, dengan kriteria unit analisis minimal sudah lebih dari 1 tahun mengajar dan telah menjadi guru tetap / tidak tetap Yayasan. Kerangka penelitian yang diujikan adalah sebagai berikut:

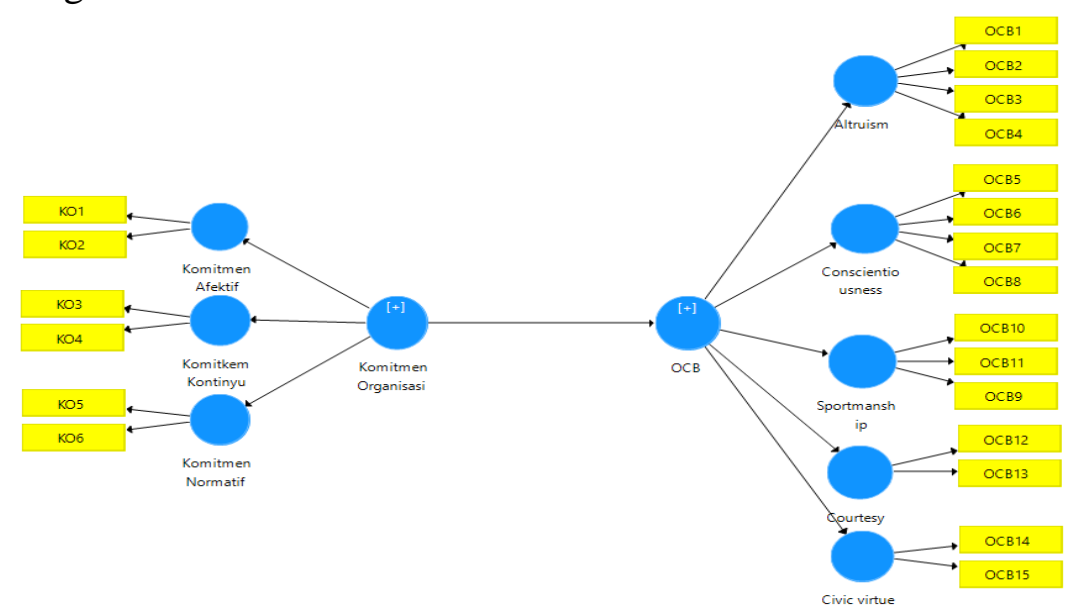

Gambar 1. Kerangka Penelitian

Adapun hipotesis yang diujikan adalah sebagai berikut: 
Prosiding The 1st National Conference on Applied Business, Education, \& Technology (NCABET)"

Unversitas Bina Bangsa 2021

DOI Article : 10.46306/ncabet.v1i1.26

H1: Komitmen afektif berpengaruh signifikan terhadap komitmen organisasi pada SD Swasta di Kota Serang.

H2: Komitmen kontinyu berpengaruh signifikan terhadap komitmen organisasi pada SD Swasta di Kota Serang.

H3: Komitmen normatif berpengaruh signifikan terhadap komitmen organisasi pada SD Swasta di Kota Serang.

H4: Altruism berpengaruh signifikan terhadap OCB pada SD Swasta di Kota Serang.

H5: Conscientiousness berpengaruh signifikan terhadap OCB pada SD Swasta di Kota Serang.

H6: Sportsmanship berpengaruh signifikan terhadap OCB pada SD Swasta di Kota Serang.

H7: Courtesy berpengaruh signifikan terhadap OCB pada SD Swasta di Kota Serang.

H8: Civic virtue berpengaruh signifikan terhadap OCB pada SD Swasta di Kota Serang.

H9: Komitmen organisasi berpengaruh signifikan terhadap OCB pada SD Swasta di Kota Serang.

Sedangkan sequence analisis yang dilakukan peneliti dapat dilihat pada rangkuman gambar 2 di bawah ini (Nuryanto et al., 2020):

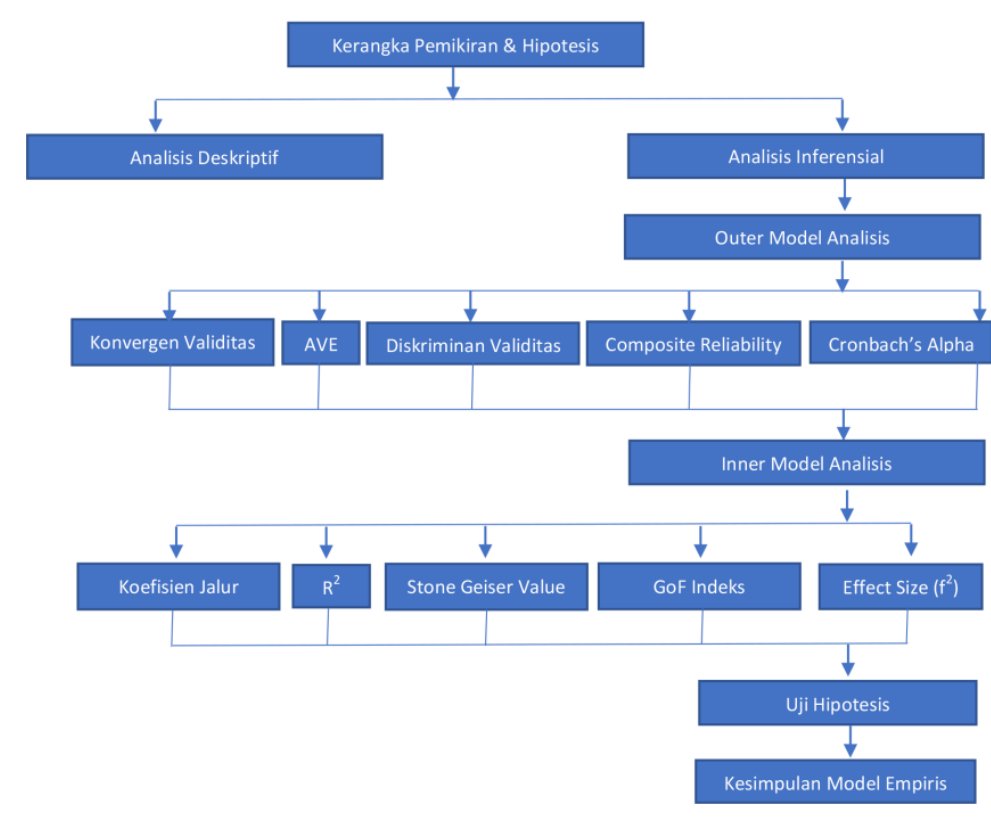

Gambar 2. Sequence Analisis Penelitian

\section{HASIL DAN PEMBAHASAN}

Deskriptif data yang diperoleh dari partisipan menyajikan identitas partisipan dari sampel pada penelitian ini yang mencakup distribusi menurut gender, umur, Pendidikan yang ditempuh 
terakhir kali dan lamanya bekerja. Penyajian deskripsi data tentang responden diuraikan dengan perangkat lunak SPSS versi 22 supaya dalam mengukur data bisa menghasilkan data yang tepat. Berikut data deskriptif responden :

Tabel 1. Distribusi Partisipan

\begin{tabular}{|c|c|c|}
\hline Demografí & Frekuensi & Percent \\
\hline \multicolumn{3}{|l|}{ Gender } \\
\hline Laki - laki & 35 & $15 \%$ \\
\hline Perempuan & 213 & $85 \%$ \\
\hline \multicolumn{2}{|c|}{ Total } & $100 \%$ \\
\hline \multicolumn{3}{|l|}{ Umur } \\
\hline $21-25$ tahun & 37 & $15 \%$ \\
\hline $26-30$ tahun & 58 & $24 \%$ \\
\hline $31-35$ tahun & 85 & $34 \%$ \\
\hline $36-40$ tahun & 45 & $18 \%$ \\
\hline$>40$ tahun & 23 & $9 \%$ \\
\hline \multicolumn{2}{|c|}{ Total } & $100 \%$ \\
\hline \multicolumn{3}{|l|}{ Pendidikan } \\
\hline SI & 243 & $99 \%$ \\
\hline $\mathrm{S} 2$ & 5 & $1 \%$ \\
\hline \multicolumn{2}{|c|}{ Total } & $100 \%$ \\
\hline \multicolumn{3}{|l|}{ Masa Kerja } \\
\hline$<1-5$ tahun & 187 & $75 \%$ \\
\hline $6-10$ tahun & 57 & $23 \%$ \\
\hline$>10$ tahun & 4 & $2 \%$ \\
\hline
\end{tabular}

Sumber : hasil pengolahan data SPSS (2021)

Hasil outer model analisis pertama terhadap parameter konvergen validitas dengan menggunakan PLS Algorithm didapatkan nilai loading faktor untuk variabel komitmen organisasi masih terdapat 1 indikator yang memiliki loading factor $<0,70$ yaitu indiktaor KO4, sedangkan untuk variabel OCB terdapat 3 indikator yang memiliki nilai loading factor $<0,70$ yaitu OCB3, OCB4 dan OCB15. Sehingga keempat indikator tersebut didroping dari model analisis yang diujikan dan untuk tahap selanjutanya dilakukan outer model analisis kedua sehingga didapatkan model analisis sebagai berikut:

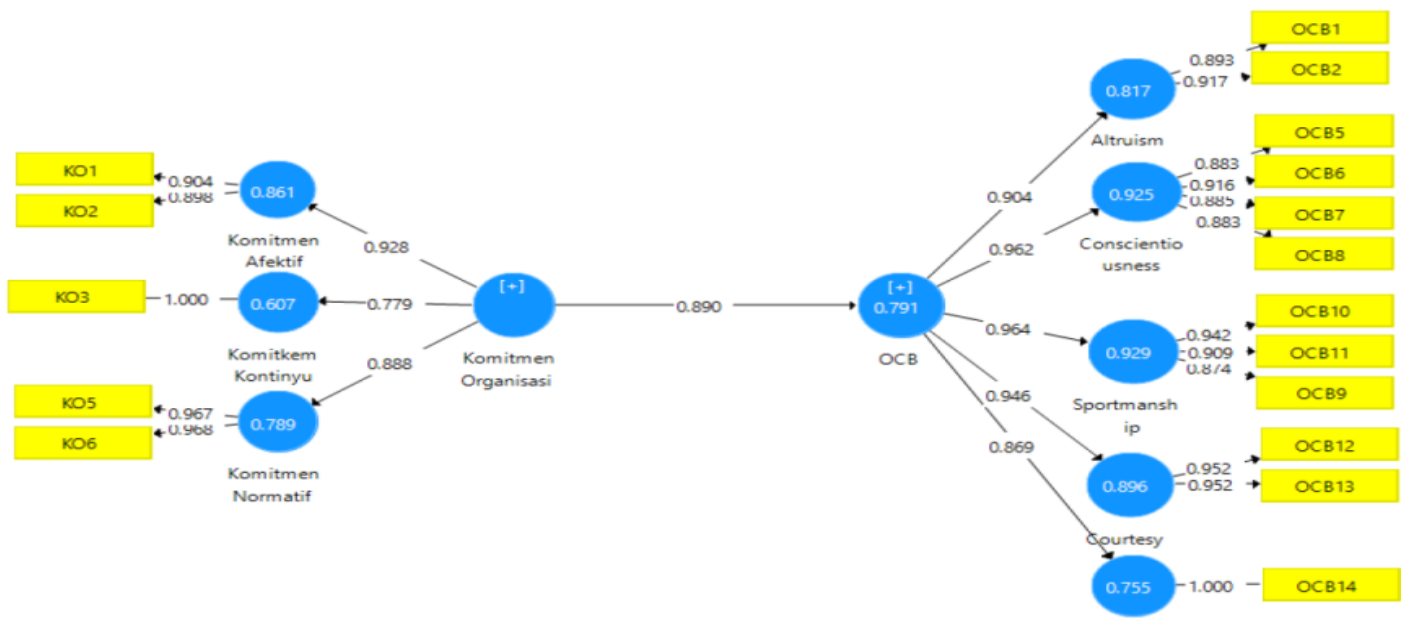

\section{Gambar 3. Hasil Outer Model Analisis Ke-2}

Dari hasil outer analisis model ke-2 terhadap parameter konvergen validitas di atas, didapatkan nilai loading faktor untuk 5 indikator terhadap dimensi komitmen organisasi telah > 0,70 dan nilai loading faktor dari ketiga dimensi terhadap variabel latenn komitmen organisasi juga telah 
$>0,70$. Sama halnya untuk ke 12 indikator terhadap dimensi OCB telah memiliki nilai $>0,70$ dan juga loading faktor dari kelima dimensi OCB telah memiliki nilai >0,70.

Sehingga dapat disimpulkan hasil konvergen validitas telah memenuhi persyaratan dimana seluruh nilai loading factor dari indicator dan juga dimensi terhadap variabel latennya valid dan mampu digunakan sebagai alat ukur untuk mengukur variabel latennya masing-masing serta mampu menjawab fenomena yang terdapat pada objek penelitian.

Hasil uji validitas kedua perkuat dengan menggunakan uji diskriminan validitas dan didapatkan hasil untuk ke 17 indkator memiliki nilai loading factor kebih besar dibandigkan nilai cross loadingnya. Hal ini menggambarkan bahwasanya masing-masing loading factor mampu dijadikan sebagai alat ukur yang valid untuk mengukur masing-masing dimensi yang diujikan.

Hasil uji validitas selanjutnya adalah Average Variance Extracted (AVE), Composite Reliability (CR) dan Alpha chronbach's didapatkan nilai sebagai berikut:

Tabel 2. Nilai AVE, CR dan Chronbach's Alpha Model Ke-2

\begin{tabular}{|l|c|c|c|}
\hline & AVE & CR & Cronbach's Alpha \\
\hline Altruism & 0,819 & 0,900 & 0,779 \\
\hline Civic virtue & 1,000 & 1,000 & 1,000 \\
\hline Conscientiousness & 0,796 & 0,940 & 0,914 \\
\hline Courtesy & 0,906 & 0,950 & 0,896 \\
\hline Komitmen Kontinyu & 1,000 & 1,000 & 1,000 \\
\hline Komitmen Afektif & 0,812 & 0,896 & 0,769 \\
\hline Komitmen Normatif & 0,936 & 0,967 & 0,932 \\
\hline Komitmen Organisasi & 0,697 & 0,920 & 0,891 \\
\hline OCB & 0,747 & 0,972 & 0,969 \\
\hline Sportmanship & 0,826 & 0,934 & 0,894 \\
\hline
\end{tabular}

Sumber: Hasil Pengolahan Data SmartPLS (2021)

Dari hasil Tabel 1 dapat diinterpretasikan bahwasanya untuk AVE dari dimensi komitmen organisasi yang terdiri dari komitmen kontinyu, komitmen afektif dan komitmen normatif memiliki nilai > 0,50 sehingga dapat digambarkan nilai varians dari masing-masing indikator dalam konstruk yang ditangkap oleh variabel tersebut lebih besar dibandingkan dengan nilai varians yang diakibatkan oleh kesalahan pengukuran. Sama halnya dengan nilai AVE untuk masing-masing dimensi altruism, conscientiousness, sportsmanship, courtesy dan civic virtue memiliki nilai AVE > 0,50 yang menggambarkan seluruh dimensi pad model penelitian valid karena memiliki nilai varians error penelitian < dari varians masing-masing indicator dalam konstruknya. Untuk variabel laten komitmen organisasi memiliki nilai AVE 0,697 dan OCB memiliki nilai AVE 0,747 dimana nilai ini > 0,50 sehingga secara struktural indikator dan dimensi yang digunakan untuk mengukur variabel laten memiliki varians yang baik.

Hasil uji CR dari indikator masing-masing dimensi komitmen organisasi memiliki nilai CR > 0,70 dimana nilai menggambarkan konsistensi yang sangat reliabel, sama halnya untuk nilai CR dimensi terhadap variabel latennya memiliki nilai CR > 0,70. Sedangkan untuk indicator dari masingmasing dimensi OCB memiliki nilai CR > 0,70 dan dimensi OCB terhadap variabel latennya juga 
memiliki nilai $\mathrm{CR}>0,70$. Hal ini menggambarkan konsistensi dari indicator dan dimensi yang digunakan untuk mengukur variabel latennya masing-masing. Untuk memperkuat hasil CR, didukung dengan nilai Alpha cronbach's, dimana nilai untuk alpha chronbach's masing-masing indicator dan dimensi didapatkan nilai > 0,60 yang menggambarkan konsitensi yang sangat baik.

Dari kelima parameter outer model analisis, didapatkan seluruh parameter telah sesuai edngan yang dipersyaratkan. Untuk kselanjutanya dilakukan inner model analisis terhadap model kedua dengan menggunakan Bootstraping dan didapatkan hasil sebagai berikut:

Tabel 3. Hasil Inner Model Analisis Model Ke-2

\begin{tabular}{|l|c|c|c|}
\hline & Path Coefficient & T Statistic & P Values \\
\hline Komitmen Organisasi $\rightarrow$ Komitmen Afektif & 0,928 & 67,991 & 0,000 \\
\hline Komitmen Organisasi $\rightarrow$ Komitmen Kontinyu & 0,779 & 19,205 & 0,000 \\
\hline Komitmen Organisasi $\rightarrow$ Komitmen Normatif & 0,888 & 36,789 & 0,000 \\
\hline OCB $\rightarrow$ Altruism & 0,904 & 48,948 & 0,000 \\
\hline OCB $\rightarrow$ Conscientiousness & 0,962 & 128,841 & 0,000 \\
\hline OCB $\rightarrow$ Sportmanship & 0,964 & 158,317 & 0,000 \\
\hline OCB $\rightarrow$ Courtesy & 0,946 & 89,219 & 0,000 \\
\hline OCB $\rightarrow$ Civic Virtue & 0,869 & 36,409 & 0,000 \\
\hline KO $\rightarrow$ OCB & 0,890 & 40,235 & 0,000 \\
\hline
\end{tabular}

Sumber: Hasil Pengolahan Data SmartPLS (2021)

Hasil inner model analisis di atas dapat diinterpretasikan untuk variabel komitmen organisasi maka dimensi yang paling dominan berpengaruh adalah komitmen afektif dengan koefisien jalur paling besar dibandingkan dimensi lainnya yaitu 0,928, sedangkan dimensi kontinyu sebesar 0,770 dan dimensi normative sebesar 0,888. Dari hasil ini maka persamaan structural untuk variabel laten komitmen organisasi adalah sebagai berikut:

$$
\eta_{1}=0,928 \varepsilon_{1}+0,779 \varepsilon_{2}+0,888 \varepsilon_{3}+e
$$

Sedangkan hasil koefisien jalur untuk variabel laten OCB didominasi oleh dimensi sportsmanship sebesar 0,964 sedangkan masing-masing dimensi lainnya adalah sebesar 0,904 untuk dimensi altruism, 0,962 untuk dimensi conscientiousness, 0,946 untuk dimensi courtesy dan 0,869 untuk dimensi civic virtue. Dari hasil koefisien jalur tersebut maka didapatkan persamaan structural yang kedua untuk variabel laten OCB adalah sebagai berikut:

$$
{ }^{\eta_{2}}=0,904 \varepsilon_{4}+0,962 \varepsilon_{5}+0,964 \varepsilon_{6}+0,946 \varepsilon_{7}+0,869 \varepsilon_{8}+e
$$

Hasil koefisien jalur variabel komitmen organisasi terhadap variabel OCB didapatkan nilai koefisien sebesar 0,890. Nilai koefisien jalur tersebut sangatlah besar dari sebauh prediktor terhadap criterionnya, sehingga dapat dikatakan bahwasanya komitmen organisasi merupakan prediktor yang esensial bagi OCB. Adapun persamaan struktural dari variabel komitmen organisasi terhadap OCB adalah sebagai berikut:

$$
{ }^{n} 3=0,890 \varepsilon_{9}+e
$$

Hasil $\mathrm{R}$ square $\left(\mathrm{R}^{2}\right)$ dari masing-masing dimensi dan juga variabel latennya didapatkan nilai secara keseluruhan termasuk kategori tinggi sebagaimana terangkum pada tabel 3. Dengan besarnya nilai R2 variabel OCB 0,791 sehingga didapatkan nilai Koefisien determinasi (KD) sebesar 79,1\% 
Prosiding The 1st National Conference on Applied Business, Education, \& Technology (NCABET)"

Unversitas Bina Bangsa 2021

DOI Article : 10.46306/ncabet.v1i1.26

sedangkan sisanya sebesar 20,9\% dipengaruhi oleh variabel lainnya diluar model yang diujikan.

Besarnya nilai ini sangatlah tinggi untu sebuah prediktor terhadap kriterionnya, yang menggambarkan pentingnya komitmen organisasi dalam memprediksi OCB.

Tabel 4. Nilai $\mathbf{R}^{2}$ dan $\mathbf{R}^{2}$ Adjusted Model Ke-2

\begin{tabular}{|l|c|c|}
\hline & R Square & R Square Adjusted \\
\hline Komitmen Kontinyu & 0,607 & 0,605 \\
\hline Komitmen Afektif & 0,861 & 0,861 \\
\hline Komitmen Normatif & 0,789 & 0,788 \\
\hline Altruism & 0,817 & 0,816 \\
\hline Conscientiousness & 0,925 & 0,925 \\
\hline Sportmanship & 0,929 & 0,929 \\
\hline Courtesy & 0,896 & 0,895 \\
\hline Civic virtue & 0,755 & 0,754 \\
\hline OCB & 0,791 & 0,790 \\
\hline
\end{tabular}

Sumber: Hasil Pengolahan Data SmartPLS (2021)

Hasil uji terhadap parameter GoF indeks dengan menggunakan persamaan $\mathrm{GoF}=\sqrt{R 2 \times A V E}$ didapatkan nilai sebesar 0,821 dimana nilai ini masuk kedalam kategori tinggi yang menggambarkan model penelitian yang dibangun memiliki tingkat kecocokan yang tinggi dan tidak terdapat perbedaan (discrepancy) antara nilai yang diobservasi dengan nilai-nilai yang diharapkan dalam model penelitian. Hasil uji terhadap parameter stone geisser value $\left(\mathrm{Q}^{2}\right)$ untuk variabel OCB sebesar 0,583 sedangkan masing-masing nilai $\mathrm{Q}^{2}$ pada tatanan model struktural untuk masing-masing dimensi nilai > 0 yang menggamabarkan nilai predictive relevance yang baik dimana masing-masing dimensi sebagai prediktor dari variabel latennya mampu memprediksi variabel laten yang dibangunnya. Dan komitmen organisasi sebagai variabel eksogen mampu memprediksi variabel endogennya dengan baik, dalam hal ini adalah variabel OCB. Secara detail, nilai masing-masing predictive relevance terangkum pada tabel 4 berikut ini:

Tabel 5. Nilai Predictive Relevance Model Ke-2

\begin{tabular}{|l|c|c|c|}
\hline & SSO & SSE & Q2 (=1-SSE/SSO $)$ \\
\hline Komitmen Afektif & 496.000 & 152.031 & 0,693 \\
\hline Komitmen Kontinyu & 248.000 & 99.762 & 0,598 \\
\hline Komitmen Normatif & 496.000 & 132.758 & 0,732 \\
\hline Komitmen Organisasi & 1240.000 & 1240.000 & 0,662 \\
\hline Altruism & 496.000 & 167.858 & 0,731 \\
\hline Conscientiousness & 992.000 & 267.126 & 0,762 \\
\hline Sportmanship & 744.000 & 177.206 & 0,805 \\
\hline Courtesy & 496.000 & 96.741 & 0,747 \\
\hline Civic virtue & 248.000 & 62.802 & 0,583 \\
\hline OCB & 2976.000 & 1240.792 & \\
\hline
\end{tabular}

Sumber: Hasil Pengolahan Data SmartPLS (2021)

Hasil parameter uji yang terakhir dengan menggunakan effect size $\left(\mathrm{f}^{2}\right)$ didapatkan seluruh dimensi memiliki kategori nilai strong effect secara parsial mengingat hasil yang didapatkan >0,40 dimana peneliti menggunakan acuan (Sungu et al., 2019). Hasil tersebut menggambarkan pengaruh dari masing-masing dimensi terhadap variabel latennya secara parsial memiliki pengaruh yang kuat. Sebagaimana dapat dilihat secara mendetail pada tabel 5 berikut ini:

Tabel 6. Nilai Effect Size $\left(\mathbf{f}^{2}\right)$ Model Ke-2

\begin{tabular}{|l|c|c|}
\hline & Komitmen Organisasi & OCB \\
\hline Komitmen Afektif & 6,214 & \\
\hline Komitmen Kontinyu & 1,544 & \\
\hline
\end{tabular}




\begin{tabular}{|l|c|c|}
\hline Komitmen Normatif & 3,738 & \\
\hline Komitmen Organisasi & & 3,792 \\
\hline Altruism & & 4,466 \\
\hline Conscientiousness & & 12,419 \\
\hline Sportmanship & & 13,183 \\
\hline Courtesy & & 8,594 \\
\hline Civic virtue Sumber: Hasil Pengolahan Data SmartPLS (2021)
\end{tabular}

Hasil uji hipotesis sebagaimana terangkum pada tabel 2 di atas didapatkan detail sebagai berikut. Untuk hipotesis pertama terkait pengaruh komitmen afektif terhadap komitmen organisasi, didapatkan nilai P Values sebesar 0,000 < probability 0,05 dan T Statistik sebesar 67,991 > 1,96 sehingga hipotesis pertama diterima, yang artinya terdapat pengaruh signifikan komitmen afektif terhadp komitmen organisasi. Hasil uji hipotesi kedua terkait pengaruh komitmen kontinyu terhadap komitmen organisasi didapatkan nilai $\mathrm{P}$ Values sebesar $0,000<$ probability 0,05 dan $\mathrm{T}$ Statistik sebesar 19,205 > 1,96 sehingga hipotesis kedua diterima, yang artinya terdapat pengaruh signifikan komitmen kontinyu terhadap komitmen organisasi. Hasil uji hipotesis ketiga terkait pengaruh komitmen normatif terhadap komitmen organisasi didapatkan nilai $\mathrm{P}$ Values $0,000<$ probability 0,05 dan nilai $\mathrm{T}$ Statistik > 1,96 sehingga hipotesis ketiga diterima, yang artinya terdapat pengaruh signifikan komitmen normatif terhadap komitmen organisasi.

Hasil uji hipotesis keempat terkait pengaruh altruism terhadap OCB didapatkan nilai P Values 0,000 < probability 0,05 dan $\mathrm{T}$ statistic 48,948 > 1,96 sehingga hipotesis keempat diterima, yang artinya terdapat pengaruh signifikan altruism terhadap OCB. Hasil uji hipotesis kelima terkait pengaruh conscientiousness terhadap OCB didapatkan nilai $\mathrm{P}$ Values $0,000<$ propbability 0,05 dan T Statistik 128,481 > 1,96 sehingg ahipotesis diterima yang artinya terdapat pengaruh signifikan conscientiousness terhadap OCB. Hasil uji hipotesis keenam terkait pengaruh sportsmanship terhadap OCB didapatkan nilai $\mathrm{P}$ Values sebesar $0,000<$ probability 0,05 dan T Statistik 158,317 > 1,96 sehingga hipotesis keenam diterima yang artinya terdapat pengaruh signifikan sportsmanship terhadap OCB. Hasil uji hipotesis ketujuh terkait pengaruh courtesy terhadap OCB didapatkan nilai P Values 0,000 < probability 0,05 dan T Statistik 89,219 > 1,96 sehingga hipotesis ketujuh diterima yang artinya terdapat pengaruh signifikan courtesy terhadap OCB. Hasil uji hipotesis kedelapan terkait pengaruh civic virtue terhadap OCB didapatkan nilai $\mathrm{P}$ Values $0,000<$ probability 0,05 dan $\mathrm{T}$ Statistik 36,409 > 1,96 sehingga hipotesis kedelapan diterima yang artinya terdapat pengaruh signifikan civic virtue terhadap OCB. Dan hasil uji hipotesis yang kesembilan terkait pengaruh variabel eksogen komitmen organisasi terhadap variabel endogen OCB, didapatkan nilai P Values 0,000 < probability 0,05 dan $\mathrm{T}$ statistic 40,235 > 1,96 sehingga hipotesis diterima yang artinya terdapat pengaruh signifikan komitmen organisasi terhadap OCB.

Hal ini dapat diartikan bahwa pendidik memiliki janji untuk asosiasi yang menyiratkan bahwa instruktur benar-benar percaya pada kualitas dalam asosiasi dan senang untuk terlibat dan memajukan 
Prosiding The 1st National Conference on Applied Business, Education, \& Technology (NCABET)"

Unversitas Bina Bangsa 2021

DOI Article : 10.46306/ncabet.v1i1.26

asosiasi yang kemudian, pada saat itu, mendorong perilaku kewarganegaraan yang otoritatif. Tinjauan ini sesuai dengan hasil pemeriksaan oleh (Sudarmayasa, 2016). Efek samping dari pemeriksaan menunjukkan bahwa tanggung jawab hierarkis memiliki dampak positif dan besar pada OCB. Hasil ini menunjukkan bahwa spekulasi yang menyatakan bahwa semakin tinggi tanggung jawab instruktur akan membangun perilaku OCB. Instruktur yang fokus pada asosiasi akan terikat untuk berbicara dengan tegas tentang asosiasi, membantu rekan kerja, dan menyebabkan pelaksanaan pekerjaan mereka melampaui asumsi biasa, menjadi penstabil dalam asosiasi, dan mengambil bagian dengan sengaja dalam latihan otoritatif.

Dari hasil penelitian didaoatkan bahwasnya komitmen organisasi merupakan bagian essensial dari OCB yang pada akhirnya menunjang kinerja guru dan kinerja sekolah. Untuk itulah pengembangan dimensi dari komitmen organisasi perlu diperhatikan. Dimensi afektif merupakan perasaan emosional yang muncul dari seseorang terhadap organisasinya disertai dengan keyakinan yang dimiliki terhadap nilai-nilai yang terdapat pada organisasi. Dimendi kontinyu merupakan komitmen yang didasarkan terhadap nilai ekonomi yang didapatkan apabila karyawan tersebut tinggal dalam organisasnya. Dan komitmen nomatif adalah komitmen yang didasarkan kepada kewajiban individu untuk tetap tinggal pada organisasinya dengan alasan moral atau etis (Steyrer et al., 2018). Pada penelitian ini secara empiris didapatkan komitmen faektif menjadi dominator bagi komitmen organisasi. Hal tersebut menggambarkan mayoritas guru pada SD Swasta di Kota serang memiliki keyakinan yang tinggi terhadap nilai-nilai yang ada pada Sekolahnya masing-masing.

Dimensi altruism merupakan perilaku seseorang dalam menolong rekan kerjanya yang mengalami kesulitan dalam situasi yang dihadapi maupun dalam hal mengerjakan tugas dalam organisasi dan masalah pribadi. Sehingga dapat dikatakan bahwasanya dimensi ini adalah menolong seseorang diluar tanggungannya. Dimensi conscientiousness merupakan perilaku kerja melebihi yang diharapkan organisasi, yang jauh melampaui apa yang seharusnya dapat diterima. Ukuran sportivitas adalah perilaku yang toleran terhadap kondisi yang kurang baik dalam pergaulan tanpa menyinggung kritik, sehingga akan lebih bijaksana dalam membantu orang lain dan membangun tempat kerja yang menyenangkan. Ukuran keanggunan adalah mengikuti perilaku yang dapat diterima dengan rekan kerja untuk menghindari masalah relasional, perilaku ini diidentifikasi dengan rasa hormat dan penghargaan terhadap orang lain. Ukuran cita-cita kota adalah perilaku yang menunjukkan tanggung jawab dalam kehidupan yang berwibawa, misalnya, mengikuti perubahan hierarkis, meningkatkan dan menyarankan tugas-tugas besar dan benar, serta mengamankan aset-aset berwibawa (Ullah et al., 2018).

Berdasarkan hasil penelitian terhadap dimens OCB, maka dimensi sportsmanship menjadi dominator bagi OCB. Hal ini dapat digambarkan bahwasanya mayoritas guru SD Swasta di Kota 
Serang memiliki perilaku yang sangat toleran terhadap keadaan yang kurang ideal dalam organisasi tanpa mengajukan keberatan, dengan perilaku sportsmanship yang tinggi maka akan meningkatkan iklim yang positif diantara para guru, terjali hubungan yang sopan dalam bekerja dan lingkungan yang kondusif.

\section{KESIMPULAN}

Berdasarkan hasil uji kesesuaian model dengan menggunakan outer model analisis dan inner model analisis maka dapat disimpulkan model ke-2 merupakan model yang ideal dengan nilai parameter dari masing-masing Batasan nilai uji. Variabel komitmen organisasi dipengaruhi paling tinggi oleh dimensi afektir sedangkan variabel OCB dipengaruhi paling dominan oleh dimensi sportsmanship. Besarnya pengaruh variabel komitmen organisasi terhadap OCB sebesar 79,1\% sedangkan sisanya sebesar 20,9\% dipengaruhi variabel lainnya diluar model yang diujikan. Dari kesembilan hipotesis yang diujikan, seluruh hipotesis diterima dengan nilai $\mathrm{P}$ Values $<0,05$ dan $\mathrm{T}$ Statistik > 1,96.

Kendati demikian penelitian ini masih menyisakan beberapa kelemaha, diantaranya adalah keterbatasan jumlah indikator pada dimensi afektif, kontinyu dan normative. Sehingga apda saat salah satu indikatornya tiak valid maka dimensi hanya memiliki sisa satu indikator. Oelh karena itu peneliti menyarankan agar penelitian selanjutnya dapat memperkaya indikator dari masing-masing dimensi komitmen organisasiselain tentunya untuk lebih menjawab fenomena yang terdapat dilapangan.

\section{UCAPAN TERIMA KASIH}

Penulis mengucapkan terima kasih yang sebesar-besar kepada Prof. Masyhudzulhak Djamil, Prof. Ngadino Surip, Prof. Pantja Djati, Prof, Mudrik Alaydrus, Prof. Apollo Daito, Prof. Willy Arafah dan Prof. Suparmoko yang telah banyak membimbing penulis selama ini dan menjadi sumber inspirasi serta panutan bagi penulis. Tidak lupa juga kami ucapkan terima kasih kepad Tim Panitia NCBET yang telah menginisiasi acara serta terima kasih kepada Bpk. Dr. Furtasan Ali Yusuf selaku Rektor UNIBA yang telah mendorong kami untuk selalu aktif dalam melakukan inovasi dan mendorong untuk selalu kreatif dalam melakukan riset yang berkualitas.

\section{DAFTAR PUSTAKA}


Prosiding The 1st National Conference on Applied Business, Education, \& Technology (NCABET)"

Unversitas Bina Bangsa 2021

DOI Article : 10.46306/ncabet.v1i1.26

Dahlan, F. (2020). Pengaruh komitmen organisasi dan budaya organisasi terhadap kinerja Organisasi Perangkat Daerah Kota Tidore Kepulauan. Indonesia Accounting Journal, 2(2), 196. https://doi.org/10.32400/iaj.31212

Massoud, A. H., Jameel, A. S., \& Ahmad, A. R. (2020). Stimulating Organizational Citizenship Behavior by Applying Organizational Commitment and Satisfaction. 02(02), 20-27.

Massoudi, A. H., Jameel, A. S., \& Ahmad, A. R. (2020). Stimulating Organizational Citizenship Behavior by Applying Organizational Commitment and Satisfaction. International Journal of Social Sciences and Economic Review, 02(02), 20-27. https://doi.org/10.36923/ijsser.v2i2.58

Nurwahidah, N., \& Jamil, M. (2020). Pengaruh Komitmen Organisasi terhadap Kinerja Organisasi Bank Syariah: Peran Turnover Intention sebagai Variabel Intervening. Ekonomis: Journal of Economics and Business, 4(2), 295. https://doi.org/10.33087/ekonomis.v4i2.171

Nuryanto, U. W., Djamil, M., Sutawidjaya, A. H., \& Saluy, A. B. (2020). Strategi Peningkatan Kinerja Dosen Melalui Pengembangan Dimensi Modal Sosial Pada Perguruan Tinggi Swasta Di Kota Serang (Studi Kasus Pada Perguruan Tinggi Swasta di Kota Serang). JURNAL MANDIRI : Ilmu Pengetahuan, Seni, Dan Teknologi, 4(1), 14 25. https://doi.org/10.33753/mandiri.v4i1.96

Organ, D. W. (2015). Organizational Citizenship Behavior. International Encyclopedia of the Social \& Behavioral Sciences: Second Edition, 317-321. https://doi.org/10.1016/B9780-08-097086-8.22031-X

Putro, P. U. W. (2018). Etika Kerja Islam, Komitmen Organisasi, Sikap Pada Perubahan Organisasi Terhadap Kinerja. Jurnal Manajemen Indonesia, 18(2), 116. https://doi.org/10.25124/jmi.v18i2.1205 
Risna, M., \& Omar, C. (2019). How Important are OCB as Mediation in Relationship Between Job Satisfaction, Motivation, Organizational Comittments, and Organizational Performance. 4(7), 15-23. https://doi.org/10.4108/eai.10-9-2019.2289393

Salim, B. alzefiti musabah, \& Noor, M. azmi. (2017). The Influence of Organizational Commitment on Omani Public Employees' Work Performance The Influence of Organizational Commitment on Omani Public Employees' Work Performance. International Review of Management and Marketing, 7(2), 151-160. https://ideas.repec.org/a/eco/journ3/2017-02-22.html

Sitio, V. S. S. (2021). Pengaruh Komitmen Organisasi dan Budaya Organisasi Terhadap Kinerja Karyawan dengan Organizational Citizenship Behavior Sebagai Variabel Intervening Pada PT. Emerio Indonesia. Jurnal Ilmiah M-Progress, 11(1), 22-37.

Steyrer, J., Schiffinger, M., \& Lang, R. (2018). Organizational commitment-A missing link between leadership behavior and organizational performance? Scandinavian Journal of Management, 24(4), 364-374. https://doi.org/10.1016/j.scaman.2008.04.002

Sudarmayasa, I. G. A. (2016). ORGANISASAIONAL DAN ORGANIZATIONAL CITIZENSHIP ( Studi pada Kantor Pusat Universitas Udayana) Fakultas Ekonomi dan Bisnis Universitas Udayana (UNUD), Bali, Indonesia Email : keplur_ama@yahoo.com ABSTRAK PENDAHULUAN Universitas Udayana (Unud) sebagai. 11, 3617-3646.

Sungu, L. J., Weng, Q., \& Xu, X. (2019). Organizational commitment and job performance: Examining the moderating roles of occupational commitment and transformational leadership. International Journal of Selection and Assessment, 27(3), 280-290. https://doi.org/10.1111/ijsa.12256

Suriana Latif, T. S. (2019). Peran Guru Dalam Meningkatkan Kualitas Sekolah Unggulan (Studi Kasus SMA Negeri 11 Pangkep dan SMA Negeri 13 Pangkep). Jurnal Sosialisasi; Jurnal Hasil Pemikiran Dan Pengembangan Keilmuan Sosiologi Pendidikan, 6(1), 99-104.

Taamneh, A., Alsaad, A. K., \& Elrehail, H. (2018). HRM practices and the multifaceted nature of organization performance: The mediation effect of organizational citizenship behavior. EuroMed Journal of Business, 13(3), 315-334. https://doi.org/10.1108/EMJB02-2018-0010

Thevanes, N., \& Harikaran, S. (2020). Work-Life Balance and Organizational Performance: The Mediating Role of Organizational Citizenship Behavior. Asian Journal of Social Sciences and Management Studies, 7(4), 280-287. https://doi.org/10.20448/journal.500.2020.74.280.287

Ullah, S., Jamal, W., \& Naeem, M. (2018). The Relationship of Employee Engagement, Organizational Commitment and Organizational Citizenship Behavior. Jinnah Business Review, 6(1), 35-41. http://www.jbrc.pk 